Atlantic Coast States were transported there by tanker. Now the "Big Inch" pipe-line is delivering more than 300,000 barrels of crude oil daily to refineries on the Atlantic seaboard, while the "Little Big Inch" delivers domestic fuel oil to the New York Harbour area. The "Big-Inch" main line is 1,254 miles long and the "Little Big-Inch" 1,475 miles.

\section{SOUTH AFRICAN INSTITUTE FOR MEDICAL RESEARCH}

$\mathrm{T}$ HE annual report for 1943 of the South African Institute for Medical Research, Johannesburg, is a record of valuable war and other work. The work of the South African Medical Corps Establishment is directed from the Institute and is organized into eight sections. Their work includes the supply and administration of the seven large and fifteen small laboratories situated at military hospitals all over the Union and the two mobile laboratories based on the Institute; training of personnel in tropical medicine and laboratory work, which has been extended to naval medical officers; a military blood transfusion service, which has developed considerably; the supply of glucose saline and other fluids for intravenous use; a snake-catching unit, which caught an average of 50-75 cobras and puff-adders a month to provide venom for the manufacture of antivenene by the Institute (a larger and more permanent snake farm at Barberton is being planned and a valuable agreement has been made with the director of the Pasteur Institute, Brazzaville, French Equatorial Africa; for the supply of venoms from equatorial snakes); and a unit for catching gerbils for the use of the typhus-vaccine department, which catches about 1,000 gerbils a month. Assays of vitaminized foodstuffs have been done by the biochemical department for the Director of Supplies, the Red Cross Prisoner-of-War Parcels Section, and other authorities. The Institute is at present the only laboratory in South Africa able to undertake the assay of vitamins in foods. An important part of the war effort has been the continued production of typhus and yellow fever vaccines and other curative and protective sera for military use, and also the building up of a reserve of anti-gas-gangrene serum.

Research work has been done on pneumonia, meningitis, diphtheria, tuberculosis endotoxoid vaccine, tetanus, whooping cough, dysentery, plague, syphilis and other diseases. The enzyme purification and concentration of tetanus and diphtheria antitoxin, anti-gas-gangrene serum and polyvalent antivenene has made such progress that it is possible to plan large-scale manufacture of various antitoxins by this process. The susceptibility of various South African rodents to vole acid-fast mycobacterium of tuberculosis has been studied. Gerbils dying after a dose of $0.0001 \mathrm{mgm}$. had lesions with a histological appearance between those of tuberculosis and leprosy. Much work has been done on anti-typhus vaccines. It is claimed that experiments with the intradermal injection of typhoid vaccine have given satisfactory results; with this method less vaccine is required and there are no local or general reactions.

Considerable research work has been done on gas gangrene, one interesting result of which has been that, among eleven samples of sera of wild animals examined, the sera of two zebras, one inyala, four impala and four kudu contained $C l$. welchii antitoxin.

It has been shown for the first time that epidemic typhus in the Transkei Territory is transmitted by lice. Murine typhus and tick-bite fever also occur in this territory. By serological tests, using pure Rickettsial suspensions, it has been found possible to. differentiate between epidemic typhus, murine typhus and tickbite fever.

Entomological work has "included a study of the distribution of sandflies; species which transmit kala-azar have been found in Southern Rhodesia; this discovery is important because troops returning from areas in which kala-azar is endemic may bring home this disease. A survey of the fleas of the South African Union is also being made. Other subjects of study have been rat-mite dermatitis, due to Liponyssus bacoti, which is very common on rats in Johannesburg, intestinal myiasis due to Dipterous larvæ, the toxin found in the eggs of ticks which causes tick-paralysis and the fungal and nematode parasites of mosquito larvæ.

The Biochemical Department has done work on human nutrition, the nutrition of mosquito larvæ, carbohydrate metabolism and the mechanism of the sulphonamide methæmoglobinæmias.

The routine work of the Institute has again increased, although the military laboratories have taken over some of this. Further expansion of the Serum Production Department has been necessary. The large-scale serum-drying and freezing plant, the cost of which was borne by Sir Ernest Oppenheimer, has been completed and is in use. Very large quantities of vaccines have been produced. Typhoid endotoxin immunization in the Witwatersrand mines has reduced the annual incidence of typhoid since 1934 from $5 \cdot 26$ to $0 \cdot 25$ per 1,000 and the annual mortality from $1 \cdot 18$ to $0 \cdot 05$ per 1,000 .

The reports of the branch laboratories at Port Elizabeth and Bloemfontein indicate that these also are vigorously. developing the work of the parent Institute.

G. LAPage.

\section{AERIAL SYSTEMS FOR SHORT RADIO WAVES}

A RECENT meeting of the Radio Section of the Institution of Electrical Engineers was devoted to the presentation of two papers dealing with the theory and experimental performance of special aerial array systems for short and ultra-short radio waves.

The first paper was by E. B: Moullin and was entitled "Theory and Performance of Corner Reflectors for Aerials". For wave-lengths of about on $\theta$ metre, a convenient arrangement comprises a pair of reflecting sheets inclined to one another to form a V, with a single aerial on the bisector. Dr. Moullin shows that the field from such a system can be calculated by image treatment and that an algebraic formula can be found when the angle of the $\mathrm{V}$ or corner reflector is a proper fraction of $180^{\circ}$. A numerical example given in the paper illustrates the convenience of the Fourier series for evaluating the radiation pattern when the aerial is sufficiently distant from the apex to make the main beam much sharper than a sinusoid, and concurrently to produce side-lobes. 